\title{
Analyzing the Perceived Effectiveness of Academic Leadership in Schools of Bahawalpur, Pakistan
}

\author{
Hassan Danial Aslam \\ Lecturer, Faculty of Management Sciences, The Islamia University of Bahawalpur (Pakistan) \\ Email: Hassan.Danial@hrmars.com \\ Qaiser Suleman \\ $\mathrm{PhD}$ (Education) Scholar, Institute of Education \& Research, Kohat University of Science \\ \& Technology Kohat, Khyber Pakhtunkhwa (Pakistan) \\ Look_for_reality@yahoo.com \\ Zainab Zulfiqar \\ MS Scholar, Department of Management Sciences, The Islamia University of Bahawalpur, \\ (Pakistan) \\ Miasbah Shafaat \\ MS Scholar, Department of Management Sciences, The Islamia University of Bahawalpur, \\ (Pakistan)

\section{Rabia Sadiq} \\ MS Scholar, Department of Management Sciences, The Islamia University of Bahawalpur, \\ (Pakistan)
}

Doi:10.5296/ijld.v4i1.5338 URL: http://dx.doi.org/10.5296/ijld.v4i1.5338

\begin{abstract}
The purpose of the study was to analyze the effectiveness of academic leadership in schools of Bahawalpur (Pakistan). All the teachers teaching at secondary school level of private sector constituted population of the study. Only 100 school teachers were selected as sample through simple random sampling technique. A self-developed structured questionnaire was used as research instrument for data collection. The quantitative research methodology has been used. Statistical tools i.e., mean, standard deviation and simple percentage were used for the analysis of the data. After analysis of the data, it was concluded that that the academic leadership in schools is not as effective as it should be as per staff perception. Supervisors do not empower their teachers. Teachers are not motivated and not involved in decision making process. Teachers are not rewarded on showing excellent performance. Furthermore, they are not engaged in building ethical ambiance in school.
\end{abstract}

Keywords: Effectiveness, Academic Leadership, Schools, Teachers, Motivation

\section{Introduction}

Leadership in schools is considered very necessary in international education policy. It plays an important part in improving school results through motivation and capabilities of the school teachers and helps to improve school's environment along this it also helps in improving student performance. If school leaders are given freedom to make important decisions that would create difference and improve students' performance. OECD has 
identified different steps to improve school leadership practices that are providing leadership across different organizational structures and people which helps to meet the challenges faced by diverse schools and improve school value and effectiveness, rewards and incentives should be given on good performances, effective school boards may contribute to the success of the schools and the boards should make clear the roles and everyday jobs of the schools, leadership schooling should be given for which training programs should be organized and the training should be consistent, quality of the current leadership should be improved and should build sustainable leadership for future (OECD, 2008).

School leadership and principal leadership play an important and critical in developing and sustaining school level conditions that are believed to be important for instructional development (Rosenholtz, 1989; Halinger and Heck, 1996). Good leaders have capabilities to deal with vast population of students belonging to different culture, race, ethics etc. they properly manage them and keep them engage in different activities to boost their inner skills that are very helpful in increasing their performance. Kenneth, Karen, Stephen and Kyla, (2004) states that leaders should help out their staff members in implementing the school and classroom circumstances to boost the accomplishment of various students. Leaders should work with other school leaders and mentors/coaches that can provide support to students and their families, but by not including changing leaders' attention and control on teacher learning.

Leader is someone who possesses qualities to motivate people to do more and then become more through his actions. It can also be explained in a way that leader should know how to influence subordinates action to implement a track of action. Good citizens of a country can be made through leadership by inducing such qualities in people (Edi, 2011). Leadership is not a quality that only resides with leaders, but it is a process that is in between followers and their leaders stated by Peter (2010).It is not a restricted process which can only be followed in one way, it is approachable to anyone. Previously leadership was about boss and subordinates that how you relate to subordinates but now due to intense completion organizations think in a unique way to get done business and to make the future. As the trend is changing stereotype thinking and process are diminishing and clearing out in today's world so it wouldn't be wrong to say that leadership attributes could be observed in anyone from top to bottom in a friendly work environment. Concept of leadership is changing from power to control to generate new ideas in a better way (Mitch, 2011). According to Mitch definition of leadership (2010) leadership doesn't work by making decisions for people that is management, leadership is to lead with new ideas towards new directions supporting by a preferred way.

Leadership provides a understandable path for the schools and other organizations and gives ability for converting it to veracity. Leadership is like a street having 2 ways. Boss should be respected as well as the, subordinates. Leadership influence people to go where they ought to go. Leadership is a process that helps its followers to complete its tasks. Leadership starts when environment is changing and new threats or opportunities are being faced. The Manager requirements are to think tactically that is when leadership and follow ship is needed.

Administrative leadership includes variety of positions which manage groups of various sizes. Academic leadership strengthens the instructional core born to teach. Leadership gives a positive difference in the workplace. It requires that heads and others outline what type of differences they want to encourage and what works to encourage them (Bennett, 2004).

Academic leadership is also changing from traditional teaching styles to modernized ways of teaching and training (David, 2004). Leadership for Principals (2008) encourages the 
principal's role as an educational leader. Teacher's performance is influenced in array to get better students' wisdom and security. These are the key doings that defines the role for principals leading change that will impact positively on results for all students. Thoughts and ideas of the public management viewpoint infusing higher education often stress the need for strong and strategic academic leadership is successful adaptation to a varying environment .An academic leadership can attach a meaning to sophistical situations and can illuminate challenging scenarios that may be a more promising option for a sector where change in the years to come will be more the standard situation than the exception.

Academic leaders' job has become very complex and demanding (Friedman, 2002). Especially in large schools, leaders must play various roles, due to associated diversity and variability with the job (Nhundu, 1999). School leaders cannot lead alone they are required to cooperate with other employees making a team leadership stated by (Hester and Geert, 2009). Effective academic leaders learn as much as possible about the programs, committees and people they supervise stated by Jeffrey (2011). Tradition of higher education is to focus on academic leadership. Image of academic supervisor/leaders as co ordinations, partnership builders or entrepreneurs have gradually been cleared out internationally. Leadership has gained much importance in the business world but it is ignored at school level and is given very less importance. As the academic places are different from manufacturing and other organization so it should also be treated in a different way and different motivational practices should be used (Siddique, Aslam, Khan and Fatima, 2011).It is renowned in literature that the leadership in educational institutions play major role that is depended on the effectiveness of leadership (Huber, 2004). In literature it is well established that good leadership is vital for successful and better performing schools (Pashiardis, 2000).

Academic leaders exercise their leadership that has obviously different institutional purposes, cultures and expectations the organizations in which leaders naturally exercises their leadership. None of the academic segment could be flourishing if it isolates itself from intellectual capacity of its areas' shifting needs or fails to maintain value-adding importance within its learning, education programs and services (Michael and Michael, 2000). The effective academic leadership is diverse and not strongly patterned. The effective leader is one who engages its staff and faculty members with its areas changing needs and must renew its vision with the passage of time and requirement. Leaders must plan out to create friendly atmosphere with their peers so that they feel accepted and being valued by everyone (Rowley, 1996).

The school supervisor, vise principal, headmaster and principal are expected to take actions as a leader in the school. The accomplishment of a school to achieve the goals depends upon the ability and the capabilities of the head to lead and influence staff members. When principals influence a group to meet its goals, they are involved in leadership. Research on high school carried out has also paid attention on the principal as leader (Grant, 1982; Coleman, 1982; light foot, 1983; Boyer, 1983; Sizer, 1984). Effective leadership creates successful environment of any organization. School leadership is an extensive process and ensures that schools are the businesses that achieve academic success for their student. The significance of leadership is a worldwide concern today. Themes and the issues, and points of view and perspectives have always been talked, discussed, and planned about. In all fields, there is a need of effective leadership. Without effective leadership we are failing to achieve the target goal of our field. To get success these issues have become most wanted.

\section{Significance of the Study}


Our study regarding academic leadership would help the schools administration to

- Develop and construct a vision,

- Advance their leadership strategies,

- leadership guidance would be given to teachers and supervisors,

- Motivate teachers so that they could provide better services,

- Become technical expert

- High performance expectations should be created,

- Intensification the school culture,

- Creating and maintain a competitive school,

- Develop and constructing prevailing forms of teaching and learning,

- Observe schools performance,

- Increase the percentage of the students' societal capital respected by schools,

- Look after the development of families.

\section{Review of Related Literature}

Pakistan is a rising country; schooling system in Pakistan has come under much denunciation (Quraishi, 2004 and Siddiqui, 2007). In 1970's government nationalized private schools due to which private schools are in more demand now a days and public schools are lacked behind due to various problems such as lack of proper financial resources, poor quality of contents and facilities. Ineffective educational system in Pakistan is due to insufficient resources. Basic resources are lacking in schools of Pakistan such as buildings, furniture, drinking water, instructional materials, and teachers with desired qualifications are necessary for them to function as learning institutions. Top level public and private institutions such as University of Education, University of Management and Technology and IED Agha Khan have started working on leadership programs to develop effective leadership in schools. However, there is no credible in-service leadership program other than these universities and institutes (Farah, Muhammad and Uzma, 2010).

The principal of the schools provides academic leadership for the school of nursing in the fields of teaching and research so as to make programs according to the needs and requirements of Pakistan and other developing countries around the world. Excellent teaching is excellent practice in a leadership. Transformative teachers are those whose students make remarkable gain in academic and nonacademic learning. Leadership framework forms a roadmap for teachers to implement in their school and class room environments. Measurable goals should be set for academic achievement and life-skills learning among students. Goals must be integrated with academic content standards outlined in the national curriculum and with educational skills content values adopted by teachers in Pakistan.

\section{What is Academic Leadersip?}

The principal as a leader added new dimensions in the traditional roles of principal as educator or administrator. Leadership is not associated with position or status it is an influencing force which is based on authority and prestige (Darling, 1992). Attitude and behavior of the principal affect the atmosphere of the school. The principal in the school is expected to take steps as a leader. Effectiveness of principal plays an important role in the success of the school to achieve the goals. A small minority of faculty devotes significant time in leadership activities in school, department and university is called academic leadership. Academic leadership can be divided into three categories research, educational and administrative (Denton, 2005). 


\section{Leadership in Research}

Leadership in research is very important and should be everyone's radar. In research leadership, three atributes are requried i.e.,

- Capacity to do first-class research work

- Having a strong vision what can be done through team effort.

- Having strong interpersonal skills to motivate colleagues.

\section{Leadership in Education}

Faculty has the responsibility of quality education and education can be scholarly work. By the use of high tech class, distance learning, pc simulation and courseware we can have many opportunities of innovation.

\section{Administrative Leadership}

It includes variety of positions which manage groups of various sizes (Denton, 2005). Academic leadership strengthens the instructional core born to teach (Gonzales, 2007). Academic leadership provides practical administrative knowledge and skills to academic administrators. Positive difference at the workplace is made by the leaders. Chairs, principals deans and others heads such as vise principals, teachers, head teacher are required by the academic leadership for what works to promote them and what type of differences they want to promote (Bennett, 2004). Strategic planning and policies that are related to the administration and resourcing for the current and future educational, research, and outreach programs of the School are carried out by them. This is the first guide upon academic leadership, released in Pakistan. Excellent teaching is excellent practice in a leadership. Transformative teachers are those whose students make remarkable gain in academic and non academic learning. Leadership framework forms a roadmap for teachers to implement in their school and class room environments. Measurable and ambitious goals for academic achievement and life-skills learning among students should be set. Motivate students and communities to work hard to accomplish their goals. Chalk out the route and plan how you will achieve those goals.

\section{Factors of Academic Leadership}

Career, work motivation, and life planning, and values placement are the factors that's develops academic leadership in teachers for disseminating affective lessons to their students stated by Kathy Lacey. These factors influence people career decisions and aspirations. Academic leader has to build a strong foundation of Credibility. Credibility needs to be demonstrated and earned in four domains, namely:

- Personal credibility

- Peers credibility

- Position credibility

- Political credibility

Effective academic leaders possess and demonstrate consistently high levels of academic Curiosity. Leaders should possess curiosity if they want to engage and influence others stated by (Kennie, 2009). Collegiality possess critical importance in academic leadership, as sharing of ideas, contribution of colleagues in the fields and willingness to offer others increases the effectiveness of leadership skills. Connection between students and teachers and between teachers and teachers create a sense of academic network in which everyone can share ideas and perform various tasks in collaboration with each other. Another main factor of academic leadership is Confidence, without confidence it's difficult to influence 
others that's why it's essential that a leader should have confidence within him i.e. 'intellectual confidence' and broader 'external confidence'.

\section{Conceptual Framework}

The literature in organizational theory explains that leadership moulds the behavior of groups and individuals for attaining the objectives (Yukl, 2006). A huge body of research views that leadership in schools got the significant impact on student learning results (Bell et al., 2003; Bossert et al., 1982; Hallinger and Heck, 1998; Leithwood et al., 2006; Robinson et al., 2008; Witziers et al., 2003). This supports our own view that the empirical study of school improvement requires dynamic models that take into account changing relationships among relevant organizational processes over time (Blalock, 1989; Kelly and McGrath, 1988; Langlois, andRobertson,1993).

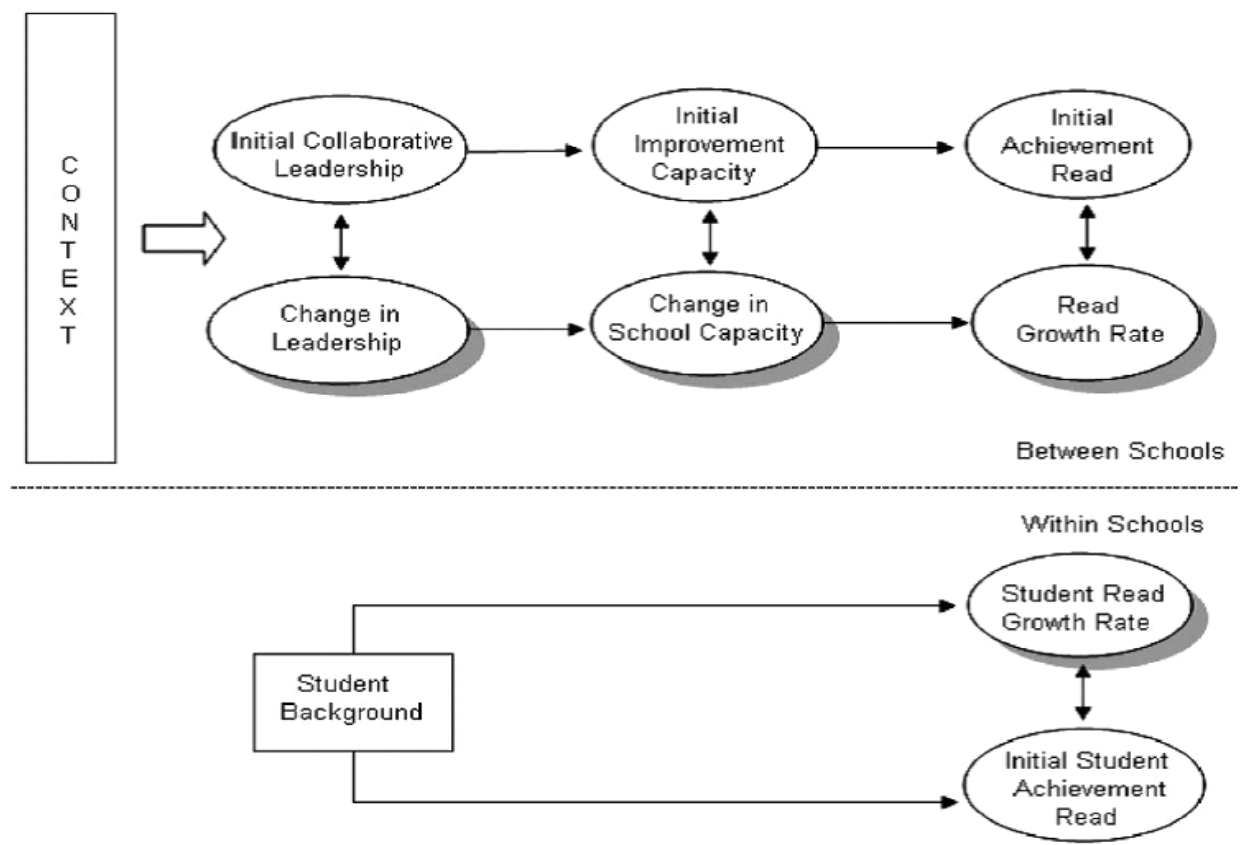

Figure 1: Conceptual Model of school improvement leadership and student learning Source: (Hallinger and Heck, 2010)

The model elaborates that variation in the degree of collaborative leadership in a given school will affect the capacity of schools academia. The pessimistic correlations between the initial level of a particular variable and its subsequent change (Hallinger and Heck, 2010). Student learning and their own learning as well are responsible by educators. Learning and leading are firmly linked in a community. There is a right for everyone, accountability and capability to be a leader and supervisor. Leadership is a fundamental aspect of an educator's professional life. Educators and policy makers similarly ask for a framework for academic leadership that will produce sustainable and desirable school improvement.

- Students, parents, teachers and principals all should participate together as mutual learners and leaders.

- Decision and practice is based on use of information. Teachers, principals, parents and students examined to find answers and pose new questions.

- Procedures imitate extensive involvement, collaboration and collective accountability.

- Deep practice every time leads to originality. Leaders/supervisors should reconsider how to do things in a proper way that leads to a new and healthier path ways.

- Achievement of students should be steadily and highly improved. Achievement of students in context of leadership capability is much broader. 
Leadership management is extensively used as an important and main factor responsible for differences in the accomplishment by which institutions like schools foster the knowledge of students. Some other schools also responsible to such changes, leadership are the catalyst. It should be further understood that who gives such type of leadership and how it is managed and distributed along with other schools (e.g., state, district, school and classroom) and what helps for progression. There is also need to understand how much learning is required and how to foster students learning and that what creates a contribution to students learning. Leithwood, Louis, Anderson and Wahlstrom (2004) assume the framework that explains that effectiveness of teachers in classrooms is that variation in workplace performance (e.g., instructional skills), responsibility and obligation and motivations of employees at work, the uniqueness of their work (e.g., schools, districts) and the outside atmosphere (shifting state policies and other demands). This framework reflects that leaders have great influence in sustaining and identifying an environment for learning. Variations in the framework are used in the context of education to understand better how schools should respond to policies and to make apparent variation in completion of work in schools put into operation and incorporate new policies and practices. A significantly expanded version of the framework is summarized in Figure 1 which serves as the organizer for this review of literature.

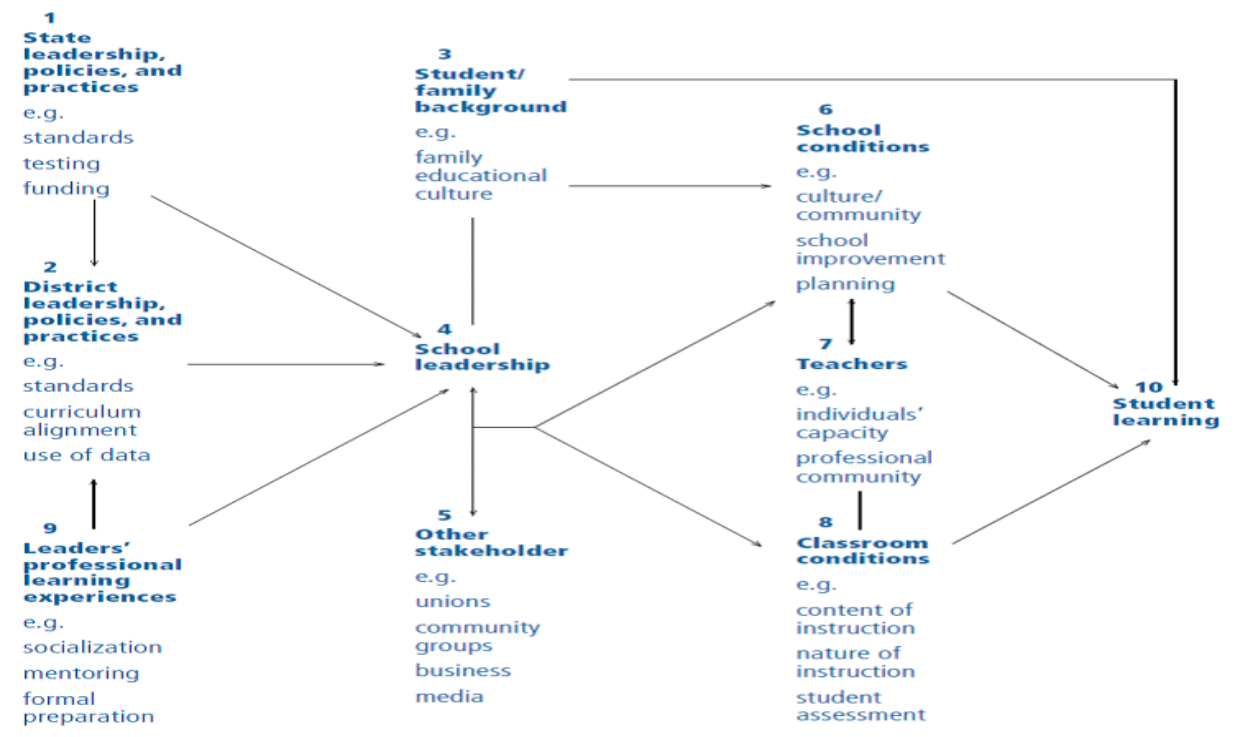

Figure 2: Linking Leadership to Learning: The research framework features 10 independent variable. This figure cannot show the many complex relationships that actually exist among the 10 variable. The relationships depicted in the figure are illustrative only.

Source: (Leithwood, Louis, Anderson and Wahlstrom, 2004)

According to Figure 2, features of both state (var.1) and district (var.2) leadership, policies, practices and other characteristics interact with one another and exert a direct influence on what school leaders do (var. 4); they also exert influence on school (var. 6) and classroom (var. 8) conditions, as well as on teachers' professional community (var. 7). Other stakeholder groups (var. 5), such as the media, unions, professional associations and community and business groups, also have influence on school leadership practices, as do leaders' professional learning experiences (var. 9). Student and family background factors (var. 3 ) have a significant bearing on most other variables and relationships in this framework. School leadership (var. 4) from both formal and informal sources helps to shape the nature of school conditions (var. 6) such as goals, culture, structure and classroom conditions (var. 8). A wide collection of factors, including those in the school and classroom, help shape teachers' sense of professional community (var. 7). School and classroom conditions, teachers' 
professional community and student/family background. Educational leaders make their schools as an effective and successful work place that hold up and keep going the performance of administrators and teachers as well as students. Successful administrator headship Hart and Ogawa (1987) statistically projected the influence of teachers on the mathematics and reading achievement of students in class 6 and 12 in 70 schools of California school, whereas scheming for environmental and organizational variables. The teachers and supervisors do have an influence on student performance.

There are two Research studies one in the United States and the other in Canada. These studies identify the characteristics of academically effective school districts. Murphy and Hallinger (1988) studied 12 high performing California school districts. They associated district effectiveness with:

- There is instructionally strong and focused leadership from the leaders

- Teaching and learning improvement are emphasized on student achievement.

- The improvement of district goals should be enforced.

- Curriculum and textbook should be adopted district wide

- Support for use of specific instructional strategies

- Purposeful selection of principals with curriculum knowledge

- Efficient monitoring between district expectations and school goals, accomplishment through principal accountability processes

Case studies of school district and school provides policy developing responsibility of districts described by Fuhrman and Elmore (1990). Schools employees can exert a strong influence on educational polices and training and development of teachers as analyzed by Fuhrman and Elmore (1990). The context used to guide our inquiry in research on organizational and industrial policy has been based on general model of employee performance (Rowan, 1996). The model assumes that variations in professional performance are a function of the capacities and workplace employees motivations, the features of the organizational setting in which they work, and the external social and political environment. Drawing on this model, Leadwood, Jantzi, and Mascall (2002) have developed a framework that can help to guide research on large-scale reforms. Their framework suggests that variations in the success of large-scale reform can be explained in terms of their influence on educators' motivations and capacities as well as their work settings that facilitate the types of changes in school and especially classroom practices needed for significant gains in whatever student outcomes are aspired to by reformers. This framework and research is used on teacher education and motivation, increasing school capacity, and leadership practices comprising of several variables are developed, embedded in five general constructs, and the relationships among these variables and constructs (see Figure 1). By viewing this model, it is assumed that better teaching practices used by the teachers, by using quality instruction, in professional learning activities in which they are involved. 


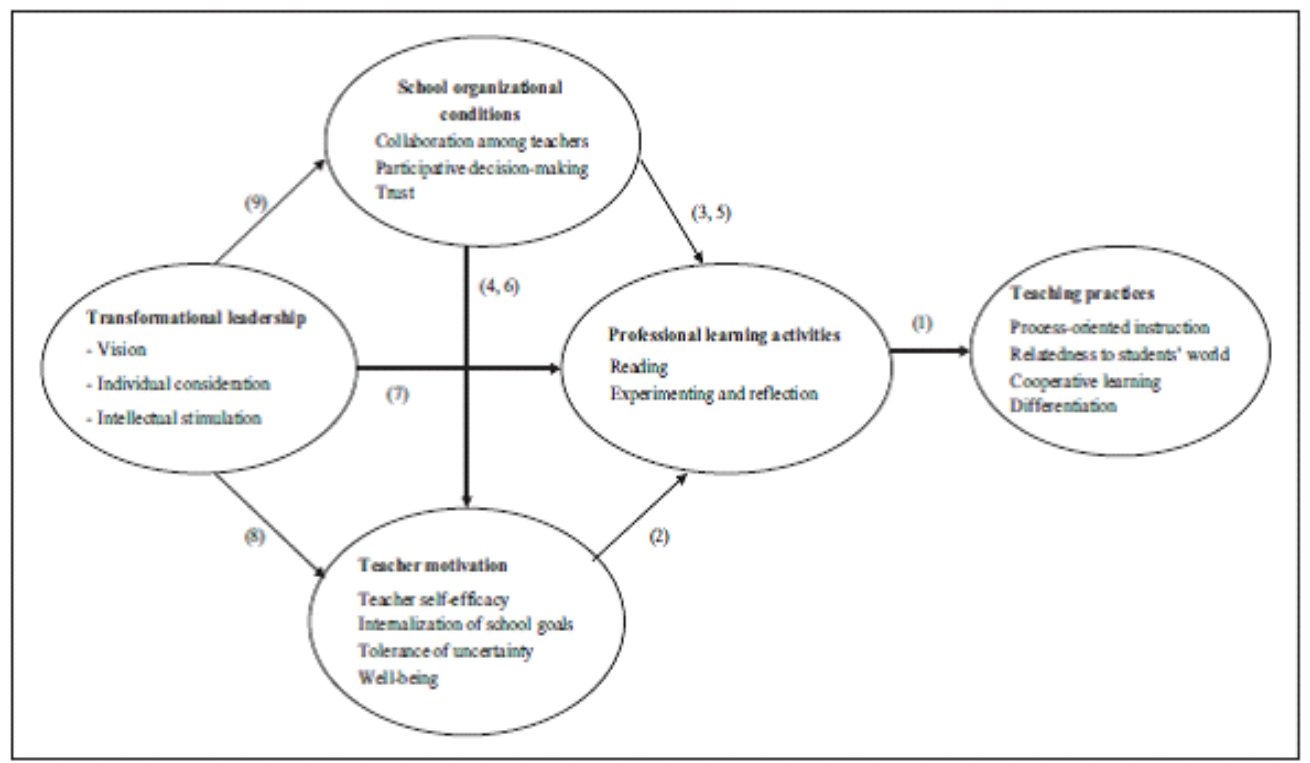

Figure 3: Theoretical Model of the relations among teacher motivational factors, school organizational conditions, leadership practices, professional learning activities and teaching practices.

Source: (Thoonen, Sleegers, Oort, Peetsma and Geijsel, 2011)

It has been shown in the latest research that increase in students' self-regulation appears to effect students' motivation and performance in a positive way, but it is not clear that whether these are applied to all students or not.(Oostdam, Peetsma, and Blok, 2007). Process-oriented instruction is the model of teaching that enables and boasts self-regulated learning. (Bolhuis and Voeten, 2001; Vermunt, 1995; Volet, 1995). According to motivational theories, positive interdependence (cooperation) is assumed to be based on inherent motivation and interaction that inspires and aids learners' efforts and high achievement, positive relationships, and psychological wellbeing are the variety of outcomes that are seen as its result (Johnson and Johnson, 1999; Krol-Pot, 2005). When students are not intrinsic motivated, teachers should reward group performance to create positive interaction and interpersonal reward structure in which group members will provide their group mates' task-related efforts that are response of withhold social strengthening. In this study, we consider teachers' learning as the engagement of teachers in three professional learning activities: keeping up to date, experimenting, and reflection. Research has shown that active learning (observing, discussion, planning, feedback, reflection) and enhancing knowledge (study groups, conferences, etc.) affect training exercise (Garet, Porter, Desimone, Birman, and Yoon, 2001; Geijsel, Sleegers, van den Berg, and Kelchtermans, 2001; Runhaar, 2008; Supovitz, 2002). According to motivational research, a difference has been made among motivational factors and motivated behavior. Motivated behavior is influenced positively by motivational factors that include teaching behavior and professional learning (Maehr and Braskamp, 1986; Roede, 1989). Three components: expectancy, value, and affective components are included in motivational factors (Peetsma, Hascher, van der Veen, and Roede, 2005; Pintrich and De Groot, 1990). In the motivational literature component of motivation has been theorized in a variety of ways that are perceived competence, self efficacy, attribution style, and control beliefs, but the basic concept involves teachers' beliefs about their capability to accomplish a task, often denoted to as teacher self-efficacy (Bandura, 1997). Self-efficacy is a future-oriented belief about the level of capability that a person expects he or she will show in a given situation. When teachers have a high intellect of self-efficacy, they tend to show greater levels of orchestrating and 
organization, are more open to new conceptions and more willing to experiment with new methods, work longer with students who are struggling, intensify their efforts when their performance falls short of their goals, and persist longer.

The affective component refers to teachers' feelings or emotional reactions to their task or the school in general. Although researchers stress the importance of analyzing teachers' emotions, systematic research on the role teachers' emotions play in promoting teachers' learning and reform processes is still missing (Hargreaves, 2001; Nias, 1996; Spillane et al., 2002; van den Berg, 2002; van Veen, 2003).

\section{Motivation of Faculty Members and Organizational Effectiveness Model}

Siddique, Danial, Khan and Fatima (2011) the link among the variables as academic leadership, motivation of faculty member and organizational effectiveness has been explored. The link is illustrated by the figure given below.

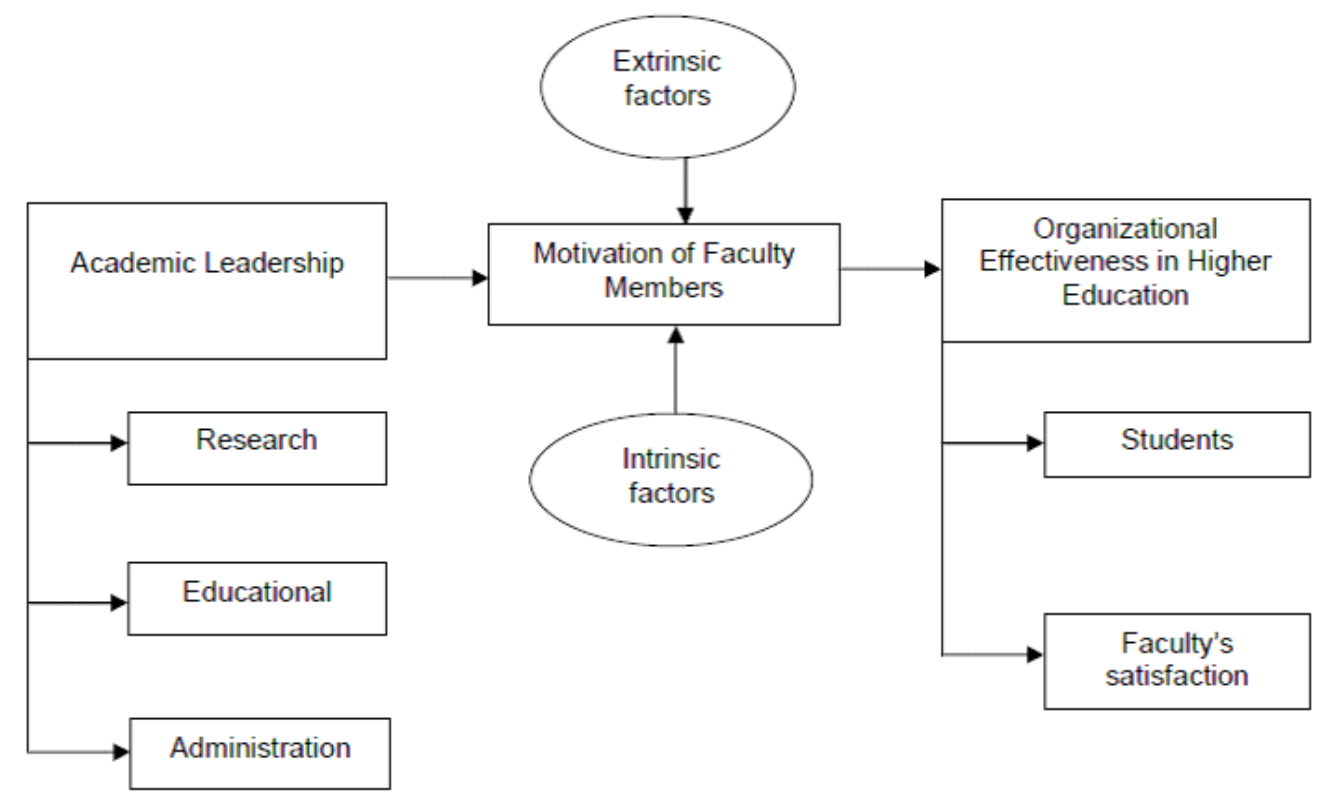

Source: (Siddique, Aslam, Khan and Fatima, 2011)

It is been stated in the model that there three types of leadership roles which can be performed by any academic leader as; administrative leadership, research leadership and educational leadership. An academic leader needs to encourage his colleagues, arrange resources for research, helps to build team and become team supervisor to accomplish mutually decided goals, and provide all the required resources to his followers. Educational leader could encourage and motivate his subordinates by providing them different type of incentives, bonuses and rewards.

\section{Murphy's Model (1990)}

Murphy (1990) gave an organized and ample analysis of instructional leadership in his research outcomes from effective school, school development, staff improvement and organizational development writings. There are four main dimensions of academic leadership, set mission and goal for future; manage educational development programs; motivating academic learning culture; and promoting cooperative working environment, these are explained below and describe different academic leader attitudes and styles which make up these four dimensions. Setting a mission and goal is very important to create a feeling of shared aim and aligning the efforts of school towards coordinated vision (Murphy, 1990). These 
dimensions have been broke down into two main behaviors and styles: developing school goals and disseminating these goals, developed goals should align with the personal goals of students , integrate the data of current and previous results of students and include the teachers duties to attain the goals of students. The developed goals should be formally and informally communicated with teachers, students and their parents so they should have known how of what they are going to accomplish in future and also stress on the importance of the goals. Management of the educational production program of schools is other dimension of Murphy's (1990) framework. The management behavior of the principal is the focus of this study. The academic leader needs to promote the quality tutoring by teaching teachers through conferences and giving timely evaluation and timely visiting the lecture halls, provide suggestions and ideas to teachers and give them feedback continuously, and give teachers the assignments which help the students. (Murphy, 1990; Teddlie andStringfield, 1985).

In the academic leadership the climate refers that the attitude of the principal should effects the values, norms, beliefs and the attitudes of teachers, students and their parents (Murphy, 1990). The teaching and learning ways in the class rooms are the basic focus of this dimension. The concluding dimension of Murphy's (1990) framework, promoting the cooperative and friendly environment, indicates that how an academic leader should establish managerial arrangements and procedures which support the schooling and education method.

\begin{tabular}{|c|c|c|c|}
\hline $\begin{array}{l}\text { Developing } \\
\text { Mission and } \\
\text { Goals }\end{array}$ & $\begin{array}{l}\text { Managing the } \\
\text { Educational } \\
\text { Production } \\
\text { Function }\end{array}$ & $\begin{array}{c}\text { Promoting an } \\
\text { Academic } \\
\text { Learning } \\
\text { Climate }\end{array}$ & $\begin{array}{l}\text { Developing a } \\
\text { Supportive } \\
\text { Work } \\
\text { Environment }\end{array}$ \\
\hline $\begin{array}{l}\text { - } \begin{array}{l}\text { Framing school } \\
\text { goals }\end{array} \\
\text { - Communicating } \\
\text { school goals }\end{array}$ & $\begin{array}{l}\text { Promoting } \\
\text { quality } \\
\text { instruction } \\
\text { Supervising and } \\
\text { evaluating } \\
\text { instruction } \\
\text { Allocating and } \\
\text { protecting } \\
\text { instructional } \\
\text { time } \\
\text { Coordinating } \\
\text { the curriculum } \\
\text { Monitoring } \\
\text { student progress }\end{array}$ & $\begin{array}{l}\text { Establishing } \\
\text { positive } \\
\text { expectations } \\
\text { and standards } \\
\text { Maintaining } \\
\text { high visibility } \\
\text { - Providing } \\
\text { incentives for } \\
\text { teachers and } \\
\text { students } \\
\text { Promoting } \\
\text { professional } \\
\text { development }\end{array}$ & $\begin{array}{l}\text { - Creating a safe } \\
\text { and orderly } \\
\text { learning } \\
\text { environment } \\
\text { Providing } \\
\text { opportunities } \\
\text { for meaningful } \\
\text { student } \\
\text { involvement } \\
\text { Developing } \\
\text { staff } \\
\text { collaboration } \\
\text { and cohesion } \\
\text { Securing } \\
\text { outside } \\
\text { resources in } \\
\text { support of } \\
\text { school goals } \\
\text { Forging links } \\
\text { between the } \\
\text { home and the } \\
\text { school. }\end{array}$ \\
\hline
\end{tabular}

Table 2.2 Murphy's Comprehensive Instructional Leadership Framework (1990)

Source: (Murphy, 1990)

\section{Weber's Model (1996)}

Weber's model (1996) about academic leadership joins research about mutual leadership and delegation of informal leaders which helps to create the schools which emphasize on the academic achievements of all students. Weber's model is summarized in Table: 


\begin{tabular}{|c|c|c|c|c|}
\hline $\begin{array}{l}\text { Defining the } \\
\text { School's } \\
\text { Mission }\end{array}$ & $\begin{array}{l}\text { Managing } \\
\text { Curriculum } \\
\text { and } \\
\text { Instruction }\end{array}$ & $\begin{array}{l}\text { Promoting a } \\
\text { Positive } \\
\text { Learning } \\
\text { Climate }\end{array}$ & $\begin{array}{l}\text { Observing } \\
\text { and } \\
\text { Improving } \\
\text { Instruction }\end{array}$ & $\begin{array}{l}\text { Assessing the } \\
\text { Instructional } \\
\text { Program }\end{array}$ \\
\hline $\begin{array}{l}\text { The instructional } \\
\text { leader } \\
\text { collaboratively } \\
\text { develops a } \\
\text { common vision } \\
\text { and goals for the } \\
\text { school with } \\
\text { stakeholders. }\end{array}$ & $\begin{array}{l}\text { The } \\
\text { instructional } \\
\text { leader monitors } \\
\text { classroom } \\
\text { practice } \\
\text { alignment with } \\
\text { the school's } \\
\text { mission, } \\
\text { provides } \\
\text { resources and } \\
\text { support in the } \\
\text { use of } \\
\text { instructional } \\
\text { best practices, } \\
\text { and models and } \\
\text { provides support } \\
\text { in the use of } \\
\text { data to drive } \\
\text { instruction. }\end{array}$ & $\begin{array}{l}\text { The instructional } \\
\text { leader promotes a } \\
\text { positive learning } \\
\text { climate by } \\
\text { communicating } \\
\text { goals, establishing } \\
\text { expectations, and } \\
\text { establishing and } \\
\text { orderly learning } \\
\text { environment. }\end{array}$ & $\begin{array}{l}\text { The } \\
\text { instructional } \\
\text { leader observes } \\
\text { and improves } \\
\text { instruction } \\
\text { through the use } \\
\text { of classroom } \\
\text { observation and } \\
\text { professional } \\
\text { development } \\
\text { opportunities. }\end{array}$ & $\begin{array}{l}\text { The } \\
\text { instructional } \\
\text { leader } \\
\text { contributes to } \\
\text { the planning, } \\
\text { designing, } \\
\text { administering, } \\
\text { and analysis of } \\
\text { assessments that } \\
\text { evaluate the } \\
\text { effectiveness of } \\
\text { the curriculum. }\end{array}$ \\
\hline
\end{tabular}

Source: (Weber, 1996)

Schools face more problems in gaining the commitment of their employees as compare to businesses (Moore, diamond 2000).

\section{Factors Affecting Academic Leadership}

There are different factors which affect the academic leadership and that factors affect the performance of institute. The factors are

- Leadership styles

- Reward system

- Ethical environment

- Favoritism

\section{Leadership Styles}

There are different leadership styles adopted by institutes to achieve their goals. Normally, schools are having autocratic, democratic and bureaucratic leadership styles. Decision making authority is basically democratic leadership style but unfortunately in Pakistani schools teachers' don't have the authority for decision making and they are not asked for suggestions. In few schools teachers are not allowed to make change according to the situation. Issues in decision making authority are teachers' empowerment, teachers' opinions consideration for decision making; teachers are not allowed to share their vision and innovative ideas for the achievement of schools goals. In practice teachers are not authorized, they are not delegated for decision making, centralized decision making decreases involvement of teachers, decreases motivation level and ultimately performance of the institutes decrease.

\section{Reward System}

Teachers' individual difference is not considered in every institute. Teachers are not properly rewarded. In few schools reward system is good but in majority schools reward system is not enough good to motivate the teachers. Incentives are not given in proper way. Reward is the basic thing for which people work but in schools teachers are not rewarded properly this decreases their motivation level and affects the performance of the institute. 


\section{Development of Ethical Environment}

Supervisors claim that they focus on the development of ethical environment this increases their motivation level and increase their performance.

\section{Favoritism}

This is very important factor in academic leadership supervisors unreasonably favor few teachers and change their principles. This is very common practice in schools which greatly affects the performance of the teachers. Teachers get disappointed by this practice and stop working. This adversely affects the performance of institutes.

\section{Statement of the Problem}

The study under investigation was specially designed to analyze the the effectiveness of academic leadership in schools of Bahawalpur, Pakistan. Therefore the statement of the problem was entitled as, "Analyzing the Perceived Effectiveness of Academic Leadership in Schools of Bahawalpur, Pakistan".

\section{Purposes of the Study}

The objectives of the study were:

1. to investigate the pattern of academic leadership at secondary school level in Bahawalpur.

2. to identifiy weaknesses and strengths of academic leadership at secondary school level in Bahawalpur.

3. to suggest workable recommendations for the effective academic leadership at secondary school level in Bahawalpur.

\section{Research Methodology}

\section{Population of the Study}

A population is the group to which a researcher would like the results of a study to be generalized (Gay, 1990). All the teachers teaching at secondary school level of private sector in Bahawalpur district constituted population of this research study.

\section{Sample and Sampling Technique}

In order to ensure adequate representation of the population, only 100 school teachers teaching at secondary school level were selected as sample through simple random sampling technique.

\section{Research Instrumentation}

It was a descriptive study and a self-developed structured questionnaire was used for data collection. The questionnaire was composed of 17 closed ended items. These were designed on five point likert scales i.e. SA (Strongly Agree), A (Agree), UN (Undecided), SDA (Strongly Disagree) and DA (Disagree). These points were further coded as:

$\begin{array}{ll}\text { SA (Strongly Agree) } & =5 \\ \text { A (Agree) } & =4 \\ \text { UN }(\text { Undecided }) & =3\end{array}$


$\begin{array}{ll}\text { SDA (Strongly Disagree) } & =2 \\ \text { DA (Disagree) } & =1\end{array}$

\section{Pilot Testing}

Validation and authentication of research tool is an important stage of research study for the achievement of exact and precise results. For this purpose, pilot testing was conducted in five secondary schools to eliminate the weaknesses, misconceptions and ambiguities of the questions in the questionnaire. The questionnaire was administered on 15 teachers and data was collected. In the light of statistical analysis of the data, some poor items were investigated and were deleted. Then it was revised and final version was prepared in the light of suggestions given by the experts in the field of education.

\section{Validity and Reliability}

No doubt, authentic results depend upon the reliability and accuracy of the research instrument. Reliability is the degree of consistency that an instrument or data collection procedure demonstrates whereas validity is the quality of the collection procedure of the data that enables it to measure what it intends to measure (Gay, 2005; and Masrur, 2003). Validity was checked by five experts in the field of education having doctorate degrees and their suggestions were incorporated. Originally, the questionnaire was composed of 32 items and in which six items were found poor and were deleted. The data acquired through pilot testing was analyzed to find out the reliability coefficient Cronbach's alpha. The reliability coefficient was found to be 0.86 which was acceptable according to guidelines recommended by Law (2004) as 'it will be rated excellent if the coefficient is greater than 0.80 , adequate if it lies within 0.60 to 0.79 and poor if it is less than 0.60' (Law, 2004). Statistical software SPSS (Version 17) was used to calculate the reliability.

\section{Data Collection}

The researchers personally visited to the sample secondary schools and distributed the questionnaires among the participants. Difficult terms were first explained and then the participants were told to give appropriate and exact response without any hesitation and free of bias. A total of 100 questionnaires were distributed and 100 i.e., 100\% responses were received. In this way data was collected.

\section{Data Analysis}

After collection of data, it was organized, tabulated, analyzed and interpreted. The statistical tools i.e., mean, standard deviation and simple percentage were used for the statistical analysis of the data. SPSS (Version 17) was used to calculate mean and standard deviation.

\section{Analysis and Data Interpretation}

The study was speically desinged to analyze the effectiveness of academic leadership in schools of Bahawalpur (Pakistan). The study was descriptive and questionnaire was used as research instrument for data collection. Data was collected through personal visits. Statistical tools i.e., mean, standard deviation and simple percentage were used for the analysis of the data. The whole process is explained as under:

\section{Table 01:}

\begin{tabular}{lccc}
\hline Question & N & Mean & SD \\
\hline Supervisors can make change & 100 & 2.12 & .686 \\
\hline
\end{tabular}


In table 1 the mean score value (mean=2.12) indicates that supervisors cannot make change. It further depicts that only $6 \%$ teachers strongly agree by the statement while $13 \%$ respondents agree that supervisors can make change.

Table 02:

\begin{tabular}{lccc}
\hline Question & N & Mean & SD \\
\hline Decision making & 100 & 2.28 & .924 \\
\hline
\end{tabular}

In table 2 the mean score value (mean=2.28) shows that teachers are not involved in decision making process. It further indicates that only $8 \%$ teachers strongly agree by the statement while $15 \%$ respondents agree that they are involved in decision making.

Table 03:

\begin{tabular}{lccc}
\hline Question & N & Mean & SD \\
\hline Empowering teachers by assigning tasks & 100 & 2.25 & .936 \\
\hline
\end{tabular}

In table 3 the mean score value (mean=2.25) shows that supervisors do not empower teachers through assigning tasks and considering their needs. Furthermore it indicates that $3 \%$ respondents strongly agree by the statement while $25 \%$ respondents agree that supervisors empower teachers through assigning tasks and considering their needs.

Table 04:

\begin{tabular}{lccc}
\hline Question & N & Mean & SD \\
\hline Seek opinions for decision making & 100 & 2.22 & .965 \\
\hline
\end{tabular}

In table 4 the mean score value (mean=2.22) depicts that supervisors do not seek opinions of the teachers for school decision making. Furthermore it indicates that $11 \%$ respondents strongly agree by the statement while $25 \%$ respondents agree that they seek opinions of the teachers for school decision making.

Table 05:

\begin{tabular}{lccc}
\hline Question & N & Mean & SD \\
\hline Teacher values are understood & 100 & 2.27 & .971 \\
\hline
\end{tabular}

In table 5 the mean score value (mean=2.27) depicts that supervisors do not understand the values of teachers. Furthermore it reflects that $7 \%$ respondents strongly agree by the statement while $21 \%$ respondents agree that they understand the values of teachers.

Table 06:

\begin{tabular}{llll}
\hline Question & N & Mean & SD \\
\hline
\end{tabular}


In table 6 the mean score value (mean=2.19) depicts that supervisors do not accommodate the individual needs of teachers. Furthermore it reflects that $7 \%$ respondents strongly agree by the statement while $15 \%$ respondents agree that they accommodate the individual needs of teachers.

Table 07:

\begin{tabular}{lccc}
\hline Question & N & Mean & SD \\
\hline Teachers needs are considered & 100 & 2.22 & .877 \\
\hline
\end{tabular}

In table 7 the mean score value (mean=2.22) reflects that supervisors do not consider the needs of the teachers. Furthermore it depicts that $4 \%$ respondents strongly agree by the statement while $12 \%$ respondents agree that they consider the needs of teachers.

Table 08:

\begin{tabular}{lccc}
\hline Question & N & Mean & SD \\
\hline Individual differences are respected & 100 & 2.92 & .784 \\
\hline
\end{tabular}

In table 8 the mean score value (mean=2.92) indicates that supervisors respect individual differences in school. Furthermore it reflects that only $4 \%$ respondents strongly disagree by the statement while $24 \%$ respondents disagree that they do not respect individual differences in school.

Table 09:

\begin{tabular}{lccc}
\hline Question & N & Mean & SD \\
\hline Teachers Rewarded & 100 & 2.16 & .901 \\
\hline
\end{tabular}

In table 9 the mean score value (mean=2.16) indicates that teachers are not rewarded by supervisors. Furthermore it reflects that only $9 \%$ respondents strongly agree by the statement while $30 \%$ respondents agree that they give rewards to teachers.

Table 10:

\begin{tabular}{lccc}
\hline Question & N & Mean & SD \\
\hline Incentives provided to excel performance & 100 & 2.22 & .921 \\
\hline
\end{tabular}

In table 10 the mean score value (mean=2.22) shows that incentives provided are not enough to excel teachers' performance. Furthermore it indicates that $9 \%$ respondents strongly agree by the statement while $17 \%$ respondents agree. 
Table 11:

\begin{tabular}{lccc}
\hline Question & N & Mean & SD \\
\hline Motivation of teachers & 100 & 2.36 & .911 \\
\hline
\end{tabular}

In table 11 the mean score value (mean=2.36) reflects that supervisors do not motivate teachers. Furthermore it depicts that $9 \%$ respondents strongly agree by the statement while $23 \%$ respondents agree that they motivate teachers.

Table 12:

\begin{tabular}{lccc}
\hline Question & N & Mean & SD \\
\hline Motivation to use creative skills & 100 & 2.18 & .734 \\
\hline
\end{tabular}

In table 12 the mean score value (mean=2.18) indicates that supervisors do not motivate teachers to use creative skills. Furthermore it shows that $3 \%$ respondents strongly agree by the statement while $18 \%$ respondents agree.

Table 13:

\begin{tabular}{lccc}
\hline Question & N & Mean & SD \\
\hline Change stimulation & 100 & 2.29 & .913 \\
\hline
\end{tabular}

In table 13 the mean score value (mean=2.29) reflects that supervisors do not stimulate change when needed. Furthermore it indicates that $5 \%$ respondents strongly agree by the statement while $21 \%$ respondents agree.

Table 14:

\begin{tabular}{lccc}
\hline Question & N & Mean & SD \\
\hline Ethical standards & 100 & 2.12 & .827 \\
\hline
\end{tabular}

In table 14 the mean score value (mean=2.12) depicts that supervisors do not apply consistant ethical standards to the job. Furthermore it reflects that $3 \%$ respondents strongly agree by the statement while $15 \%$ respondents agree.

Table 15:

\begin{tabular}{lccc}
\hline Question & $\mathbf{N}$ & Mean & SD \\
\hline Influencing colleagues & 100 & 2.33 & .842 \\
\hline
\end{tabular}

In table 15 the mean score value (mean=2.33) shows that supervisors do not like influencing colleagues through his/her personal behavior. Furthermore it reflects that $6 \%$ respondents strongly agree by the statement while $21 \%$ respondents agree.

Table 16: 


\begin{tabular}{lccc}
\hline Question & N & Mean & SD \\
\hline Building ethical environment & 100 & 2.05 & .744 \\
\hline
\end{tabular}

In table 16 the mean score value (mean=2.05) reflects that supervisors do not seek to build an ethical environment. Furthermore it depicts that $4 \%$ respondents strongly agree by the statement while $13 \%$ respondents agree.

Table 17:

\begin{tabular}{lccc}
\hline Question & $\mathbf{N}$ & Mean & SD \\
\hline Favoritism & 100 & 3.09 & .839 \\
\hline
\end{tabular}

In table 17 the mean score value (mean=3.09) indicates that supervisors favor favoritism. Furthermore it depicts that $7 \%$ respondents strongly disagree by the statement while $18 \%$ respondents disagree.

\section{Discussions}

Leadership is not a quality that only resides with leaders, but it is a process that occurs between leader and followers (Peter, 2010). It is not a restricted process which can only be followed in one way, it is approachable to anyone. Previously leadership was about boss and subordinates that how you relate to subordinates but now due to intense completion organizations think in a unique way to get done business and to make the future. As the trend is changing stereotype thinking and process are diminishing and clearing out in today's world so it wouldn't be wrong to say that leadership attributes could be observed in anyone from top to bottom in a friendly work environment. Concept of leadership is changing from power to control to generate new ideas in a better way. Leadership influences the people to work for the goals they want to achieve. Leadership is a process that ensures that task should be accomplished by the followers. Leadership has three attributes; ability to do good research work, having a strong vision what can be done through team effort and having strong interpersonal skills to motivate colleagues. Multiple roles are played be the leaders working and controlling the schools variability and diversity that is related to their job. School leaders cannot lead alone they are required to cooperate with other employees making a team leadership. It is renowned educational institution achievements depends on leadership effectiveness. For better performing schools perfect leadership is essential. Educational leadership is a globally recognized. The perspective issues and views about it have always been discussed and planned out. In all fields, there is a need of effective leadership. Without effective leadership we are failing to achieve the target goal of our field. To get success these issues have become most wanted. The academic leadership is very important concept of $21^{\text {st }}$ century because the teachers are the mentors or coaches of the students. Teachers directly or indirectly affect the students in every way. Students get affected by their teachers and see them as their ideal. Students used to follow their teachers. The importance of the students cannot be neglected because students are future of any country they are the future leaders of country. Hence the teachers also need to be groomed and need to increase their vision so they can lead their students at the right them. Without teachers motivation students cannot be motivated. They are champions of change. If teachers are having power or academic leadership is focused then teachers will have power to inspire their students. 
Supervisors have the authority to make change. This would increase their motivation level and they will bring change that is in favor of the school. Supervisors must be given the power and courage to make changes if he thinks it would be good in the interest of schools, he is closely associated with the schools and knows quite well about the current situation going out and can make better decisions so he should be given power to bring change when required. The study concludes, Mostly teachers are claiming that they are not involved in decision making and $8 \%$ teachers strongly agree by the statement while $15 \%$ respondents agree that they are involved in decision making. Involvement in decision making also increase the motivation of the teachers and motivates faculty members perform well. The study reveals, commitment to innovative ideas generates more ideas and increases the school effectiveness. Innovation basically the key factor that attracts the teachers as well as students towards work and creates an environment that is attractive and pleasing for everyone. The research reaches at the conclusion, if the supervisors are able to shape the future they will think best which is in favor of school development. They can bring out lots of innovation creation if they sincerely take this work in their hands that they are here to shape the future of the students, of school and of themselves. The study shows, if supervisors exert appropriate influence on teachers he could easily convince the teachers to do what. By influencing teachers leaders can take out work from teachers what they want to. Teacher's gets inspired from charismatic leaders and that influence can be very effective for teachers to get motivated and work effectively. The study unveils, if the needs of the teachers are considered well it will motivate the teachers and create us feeling among them which would increase the performance level.

We must knowledge teachers about their skills and power which help them to enhance their leadership qualities. They should know what empowerment has done for teachers (Erlandson and Bifano, 1987), it is important that the teachers should have the same opportunities which teachers have nationwide. The study further unveils; seeking the opinions of the teachers would also increase the motivation level and increase the loyalty of teachers for the school. When teachers participate in this decision making process, this increases their commitment. Moreover, teachers have the feelings that they need to do more for school not just teach in the class rooms. This suggests that schools need to understand the importance of academic leadership the entire system will be benefited if the teachers participate in the controlling environment of school. Everyone must be provided with recent research on the participatory decision making processes and some sort of training should be provided this will help to achieve the success. If the values of the teachers are understood it would increase the respect for the supervisor and increase the loyalty of the teachers towards supervisor and school as well. Supervisors need to give freedom to teachers to remain them focused on classrooms. Bell schedules and testing dates should be well decided in advance. The collected data should be disaggregated in a way so it can be useful for teachers and students, it should arrive with clear explanation how it means and how it can help to instructor. Similarly if the individual needs are accommodated, the teachers become satisfied from the job and their supervisor and that would definitely increase the motivation and performance of the teachers. Every individual needs support from fellow workers, teachers, supervisors and administration. Students have to realize that teachers try to help their students. Every person need to understand or recognize the complexity of the system in which they are working. Schools should value the tasks teachers perform and also tell other about their effort. In fact, teachers just need respect from their supervisors. The study reaches at the conclusion, considering teacher needs will increase their commitment level and create a feeling among them that they are the superior part of the organization which would increase their performance that is helpful in increasing school effectiveness. Proper reward system and intrinsic rewards can increase teacher's morale and motivation level to thrive them to work effectively. The study concludes, Majority of respondents believes that they are respected on the basis of their skills to motivate 
them and to increase their commitment with the school. Normally people are hiding the actual situation they don't want to tell the exact scenarios actually happing inside the schools and that is due to the pressure of supervisors upon them. An individual difference creates professional jealousy and favoritism among employees due to which individual differences are not respected. The study unveils, Rewards are the tools to motivate employees hence most of the schools are trying to have an appropriate reward system. Normally supervisors are of the view that by giving low rewards and salaries they are saving the money but actually they are demotivating the employees which directly reduce their effectiveness towards their work. Therefore effective leader needs to transform him into extraordinary, ambitious, devoted and enthusiastic leader who can communicate with passion, power and charisma. The study reveals, Leaders do inspire their subordinates to take work from them. Supervisors sometimes negatively influence their subordinates and pressurize them to work the way they want to. Such behavior of supervisors could be due to biasness and favoritism with employees having close association and good terms with the supervisors but in actually they should have inspired them in a positive way.

Incentives are also the basic tool to excel the performance of employees that's way it is extremely focused in schools. People are motivated to do things because of external rewards. For example, you might be motivated to go to work each day for the monetary reward of being paid. In schools employees not gave properly incentives those results in absenteeism and high turnover. A bonus becomes part of the expected compensation package. People want positive feedback. The study reveals, motivation and Performance at workplace is valuable for employers, mood has great impacts on motivation and performance. The study reveals that work goals are greatly affected by negative attitudes. There is strong verification that some firms and working organizations emphasize on inspiration and motivation to hire and retain top quality employees, and that these effects are even greater in larger organizations. Consistent feedback is provided by the motivation. Quantitative results show that some supervisors motivate teachers through clarification of expectations. The study reveals that supervisors don't motivate their teachers to take actions, participate in school activities. Experts in the field of human motivation tell us that instead of waiting until we are motivated to take action, we need to reverse the process and take action to get motivated. The study concludes, supervisors don't motivate to express the innate skills of teachers which affect the performance of teachers. If supervisors motivate teachers to learn this helps to increase the portfolio of the school if their teachers have creative skills and innovative ideas. Most of teachers do appreciate creativity in their students, but they are not sure how to carry out the whole process as they as they are not encouraged by their supervisors. Those teachers develop creativity in themselves, their students, and others around them. Leaders when motivate the group actions and group work, this increase the efficiency and create friendliness among employees. Supervisors don't empower teachers to simulate the change when it is required or take decision in the absence of leader. If supervisors empower teachers for stimulation of change they have the feelings of empowerment and commitment. The research concludes, supervisors normally don't focus on the ethical values and standards in their schools. If supervisors focus on ethical values and increase ethical standards employees' morale values increases and inconsistencies in schools decreases.

Supervisors don't worth ethical development in their schools due to lack of exposures of supervisors. The study unveils, if supervisors focus on ethical development this increases the respect factor among colleagues. Environmental education is effective when it is well planned and developed through interactive materials for educators and learners. Major setback in the implementation of environmental education is the capacity and lack of relevant resource 
material. The study unveils; Personal behaviors of colleagues inspire each other and further motivate them. The skills required to build talent and to engage others change across leadership levels. At the first level, leaders build talent by selecting and developing their direct reports, and they engage and inspire others by frequently and directly interacting with them.

Complexity grows as the scope of leadership increases. In addition to developing and engaging their own team, executives must hold others accountable for these actions, create a positive environment, and create systems that support development of successors for key positions. The research reaches at the conclusion, Supervisors don't clear their standards or expectations to their subordinates this has negative impact on teachers because they don't know what is exactly expecting from them. When the standards are not in knowledge of the employees that what is right creates problem within employees. The study concludes, Supervisors don't consider it important to build ethical environment in schools. To increase schools effectiveness leaders focus to build ethical environment. Without ethical environment an organization cannot be successful. Problems and issues can arise to great extent when we in an organization ethics are not considered important. Respect and dignity of people hurts as everyone is habitual of misbehavior and disrespecting each other due to no proper ethical rules and regulations. The study concludes that supervisors favor their favorite teachers. This is the most observed problem in schools of Pakistan. Supervisors change their rules for favorite teachers and reward them more than deserving teachers. Favoritism discourages and de motivates the teachers, ultimately biasness will affect the performance and effectiveness of teachers as well as of the schools. The study unveils, successful leaders pay special attention in knowing the real personal and competences of themselves and they want to create successful innovation in the education system. Critical thinking should be stimulated by them. Ideas and opinions should be challenged by them from time to time and they should look for different ways to grow and learn.

\section{Conclusions}

In nutshell, it is concluded that the academic leadership in schools of Bahawalpur is not effective. Supervisors favor their favorite teachers and don't give chance to teachers to enhance their innate skills. Supervisors don't empower their teachers. Teachers are not motivated and not involved in decision making process. Teachers are not rewarded on showing good performance. Their problems are not solved. Furthermore, teachers are not engaged in building ethical ambiance in school. Practice of nepotism and favoritism is encouraged in schools.

\section{Recommendations}

Keeping in view the above conclusions, the researchers made some workable recommendations which are explained as under:

1. Supervisors should decrease the work burden on teachers and also appreciate them for their efforts.

2. Schools should make proper reward system. Reward system should accommodate the needs of teachers. The salary packages should be attractive for teachers. Reward system needs to be unbiased. Teachers need to be rewarded; awards and prizes should be given to teachers on good performance.

3. There should be no favoritism or discrimination on the basis of personal relations. Heads should deal teachers equally. Teachers should be discriminated or favored on the basis of their performance. Supervisors need to build ethical environment in the schools. Supervisor encourages the ethical development of colleagues.

4. Try to build friendly and cooperative environment. Every supervisor should listen to teacher's problem and try to solve them and they should be humble and respect the 
dignity of every teacher and treat them equally and kindly.

5. Teachers should be empowered properly, give them decision making power and give them authority to deal with their problems. Heads delegate responsibilities to teachers. Before any decision making ask the views and suggestions from teachers.

6. Supervisors should warmly welcome the new ideas given by teachers and appreciate them for their new ideas.

7. Supervisors should try to provide proper facilities required by teachers because insufficient facilities affect the performance of teachers.

8. Training and development programs showed be encouraged and focused to enhance the exposure of teachers.

9. System should be centralized; teachers should be involved in decision making. This will motivate teachers to work well.

10. Supervisors should accommodate need of teachers and offer them bonuses and incentives.

11. Teachers are allowed to share their vision. Teachers are able to visualize the future of school and they can help to set the future goals of schools. Ultimately the commitment of teachers with school will be high and this will help to attain the goals of schools.

12. Supervisors should appreciate their teachers for their efforts and give them rewards on extra effort this will help to increase the teachers' involvement with school.

\section{References}

Anum, S., Hassan, D., Mannan, K. and Urooj, F. (2011). Impact of academic leadership on faculty's Motivation and organizational effectiveness in higher education system. International journal of academic research.

Concepts of leadership (2011). Retrieved from http://www.nwlink.com/ donclark/leader /leadcon.html

David. G. (2004). Leadership in Education and E- leadership. ICT, 25(1), 113-124.

Developing teacher's leadership skills. (1991). Eric Digest. Washington. DC. Retrived from http://www.ericdigests.org/

Farah, R., Muhammad, A. and Uzma, Q. (2010). Retrieved from http://www.academicLeader ship.org/article/Authentic_Leadership_for_Democracy_in_Schools

Fire them up (n. d.). http://www.leadershipnow.com/leadershop/9780470165669.html [Retrieved on 7-3-2012].

Gay, L. R. (2005). Educational research: Competencies for analysis and application. Islamabad: National Book Foundation.

Hester, H., and Geert, D. (2009). Exploring the link between distributed leadership and job satisfaction of school leaders. 25(2), 153-171. http://www.mysdcc.sdccd.edu/Norfolk_Homeport_Training/Instructor_Info/Training_ Tips_and_Info/MOTIVATING\%20STUDENTS/Done/motivate.htm [Retrieved on 25-2-2012]. http://www.sedl.org/change/leadership/character.html [Retrieved on 3-12-2011].

Improving School Leadership, www.oecd.org/edu/schoolleadership [Retrieved on 4-12-2011].

Jacqueline, B., and Jari, Y. (2009). Promoting inclusive leadership in higher education institutions. 15(3), 277-289.

Jeffery, B. (2011). Academic leadership day by day: small steps that lead to great success. San Francisco.

Karen, D., and Michael, T. (2010). Schools leaders need specialized development.

Kenneth, L., Karen, S., Stephen, A., and Kyla, W. How leadership influences student learning. 


\section{Macrothink}

Law, M. (2004). Outcome measures rating form guidelines. Canadian Journal of Occupational Therapy, 54, 133-138

Leaders in Learning (n.d.). http://www.motivateaction.co.uk/ [Retrieved on 3-3-2012].

Leadership Characteristics that Facilitate School Change.

Masrur, R. (2003). Thesis writing: A systematic approach. Islamabad: Allama Iqbal Open University.

Metthew, W. ( 2005). General Principles of Motivation. Los Angeles Business Journal.

Mitch, C. (2004). Leadership styles. Leaders direct.

Nadia, R. (2010). Factors influencing schools effectiveness in Pakistan. http://archives.dawn.com/ [Retrieved on 4-06-2010].

Peter, N. (2010). Leadership: theory and practice. California: SAGE Publications.

Philip, H., and Ronald, H. (2010). Leadership for Learning: Does Collaborative Leadership Make a Difference in School Improvement? Educational Management Administration and Leadership, 38: 654.

Private schools in Pakistan. (2002). http://www.yespakistan.com/education/private_schools.asp [Retrieved on 4-12-2011].

Robert, S. and Wendy, W. (n.d.).Teaching for Creativity. http://www.cdl.org/resource-library/articles/teaching_creativity.php [Retrieved on 8-3-2012].

Saeid, B. (2007). Leadership in Educational Administration: Concepts, Theories and Perspectives,

http://www.academicleadership.org/article/Leadership_in_Educational_Administratio n_Concepts_Theories_and_Perspectives. [Retrieved on 3-12-2011].

Schools Leaders Need Specialized Development. (2003). Center for educational policy analysis Rutgers, the state university of new jersy 10 seminar place New Brunswick NJ 08901-1183. 